IZA DP No. 7856

Gender and Race Heterogeneity: The Impact of Increases in Students with Limited English on Native Students' Performance

Timothy M. Diette

Ruth Uwaifo Oyelere

December 2013 


\title{
Gender and Race Heterogeneity: The Impact of Increases in Students with Limited English on Native Students' Performance
}

\author{
Timothy M. Diette \\ Washington and Lee University \\ Ruth Uwaifo Oyelere \\ Georgia Institute of Technology \\ and IZA
}

Discussion Paper No. 7856

December 2013

\author{
IZA \\ P.O. Box 7240 \\ 53072 Bonn \\ Germany \\ Phone: +49-228-3894-0 \\ Fax: +49-228-3894-180 \\ E-mail: iza@iza.org
}

Any opinions expressed here are those of the author(s) and not those of IZA. Research published in this series may include views on policy, but the institute itself takes no institutional policy positions. The IZA research network is committed to the IZA Guiding Principles of Research Integrity.

The Institute for the Study of Labor (IZA) in Bonn is a local and virtual international research center and a place of communication between science, politics and business. IZA is an independent nonprofit organization supported by Deutsche Post Foundation. The center is associated with the University of Bonn and offers a stimulating research environment through its international network, workshops and conferences, data service, project support, research visits and doctoral program. IZA engages in (i) original and internationally competitive research in all fields of labor economics, (ii) development of policy concepts, and (iii) dissemination of research results and concepts to the interested public.

IZA Discussion Papers often represent preliminary work and are circulated to encourage discussion. Citation of such a paper should account for its provisional character. A revised version may be available directly from the author. 
IZA Discussion Paper No. 7856

December 2013

\section{ABSTRACT}

\section{Gender and Race Heterogeneity: The Impact of Increases in Students with Limited English on Native Students' Performance}

The influx of immigrants has shifted the ethnic composition of public schools in many states including North Carolina. Recent evidence from North Carolina suggests that increases in Limited English students' concentration have led to a slight decline in performance solely for students at the top of the achievement distribution. The heterogeneous peer effects by achievement level lead us to explore in this paper whether the increased immigration has differential effects by gender and race. Utilizing fixed effects methods that allow us to address possible endogeneity with respect to the schools' students attend, we find heterogeneous peer effects of limited English students on natives' performance in math and reading. Specifically, we find no peer effects on white females but small negative effects on males and blacks on average.

JEL Classification: I20, I21, J15, J24

Keywords: immigrants, student achievement, peer effects, education, race, gender, limited English students

Corresponding author:

Ruth Uwaifo Oyelere

School of Economics

Georgia Institute of Technology

221 Bobby Dodd Way

Atlanta, GA 30062

USA

E-mail: ruth.uwaifo@econ.gatech.edu 


\section{Introduction}

From 1980 up until the recession in 2008, immigrant inflow into the U.S. (both legal and illegal) increased dramatically. Data from the Census Bureau show that the nation's immigrant population reached 40 million in 2010 and the decade from 2000 to 2010 had the highest level of immigration in U.S history. The rise in immigrants, particularly from Latin America, has sparked debates on U.S immigration policy and concerns over possible negative effects of immigration. North Carolina, the state on which we focus our analysis, is one of the many states to have recently have eyed a tougher stance against illegal immigration. Between 1990 and 2000, North Carolina ranked highest among all states in the change in its immigrant population. North Carolina had a foreign born population of just 1 percent in 1990 which rose to 7 percent by 2008.

Diette and Uwaifo-Oyelere (2012) investigate potential peer effects of the significant increase in the concentration of Limited English (LE) students in North Carolina on achievement of native students in math and reading End-of-Grade examinations. Their results suggest a small but statistically significant negative effect of increased exposure to immigrants on math and reading scores for students in the top 25 percent of the achievement distribution but no effects on the remaining 75 percent. Further analysis suggests that the negative effect is concentrated in schools with the lowest median share of LE students. In this paper we extend this focus on possible LE student effects but search for heterogeneity across gender and racial groups. For race we focus solely on black-white differences given these are the major racial groups in the native born population in North Carolina.

Our motivation for searching for differences across gender and race in immigrant peer effects is guided by prior research showing group differences in peer effects. For example, Angrist and Lang (2004) show that the desegregation program Metropolitan Council for Educational Opportunity (Metco), that sends students from Boston schools to richer suburban schools, had no effect on white-non-Metco students but had an effect on minorities, especially girls. Similarly, Haushek, Kain and Rivkin (2009) consider the effect of having a higher concentration of black schoolmates on the outcomes of black and white students in Texas and note no effects on White 
students but significant effects on black students. Other papers that consider gender and or racial differences include Cho (2012), Hoxby (2000), Santiallo (2009), and Lavy \& Schlosser (2011).

In this paper we investigate two important questions that allow us to test for heterogeneity across groups. First, do significant shares of LE students into a school affect the academic performance of boys and girls differently and does it create similar effects on the academic achievement of Black and White students? Second, are these gender and racial differences, if any, distributed differently within the achievement distribution? These questions are important given the possible differential effects population and demographic changes can create and the need for policymakers and educators to be better informed of such heterogeneity. Moreover, given LE students are primarily immigrants and the role of immigrants has become an increasingly hot topic in a time of economic stagnation and high unemployment, it is useful to evaluate whether the presence of immigrant children in schools may reduce significantly the educational outcomes of select native children even though overall negative effects on natives may be minimal.

To address these questions, we analyze education data from North Carolina between 1998 and 2006. ${ }^{1}$ We approach answering our questions using the value-added approach common in the literature as a base model. Specifically, we estimate the impact of the level of LE student shares within a grade in a school on native student performance in time t controlling for the individual's performance in the previous period. However, given the limitation of this approach we conduct further empirical analysis controlling for potential selectivity issues using both a school fixed effects specification and a school-by-year fixed effect model. Given Diette and Uwaifo Oyelere (2012) note heterogeneity in the LE effect within the achievement distribution in North Carolina, we estimate LE student effects by gender and for blacks and whites. We divide each group into three subgroups based on if students fall into the top third, middle third, and bottom third of the achievement distribution.

Our results show clearly the limitations of a value added approach without controlling for possible selection bias, even with the inclusion of teacher and school level characteristics.

\footnotetext{
${ }^{1}$ This data is made available through the North Carolina Education Research Data Center (NCERDC).
} 
Furthermore, our results also suggest the need to go beyond a specification including only school fixed effects. This is because even within schools, unobservable over time can create a bias in the measured LE peer effect. For example, our estimated peer effects using only a school fixed effect specification seem to suggest negative impacts of increases in LE students on females. However once we estimate our model including school by year fixed effects, we find no significant effect of the share of LE students on native female students. In contrast for males, we find a significant negative effect in both math and reading when we include school by year fixed effects. The results by race also suggest heterogeneous impacts. We find negative LE peer effects on black students in both reading and math. We also note heterogeneity in the effects within the achievement distribution. Specifically, when we concentrate on the top third of the achievement distribution, we find negative peer effects for black males in reading and negative peer effects for white males in math and reading. In the middle third of the distribution, we find negative peer effects for black females in both math and reading, and negative effects for black and white males in reading. We do not find any effects on white females and on students at the bottom of the achievement distribution.

The remainder of this paper is organized as follows. Section 2 provides an overview of the literature review. Section 3 details the data we will be using. Section 4 provides some summary statistics. Our methodological approach for answering the research questions is in section 5. Section 6 highlights our preliminary and primary results. Our robustness checks on the sensitivity of our results are in section 7 . We conclude in section 8.

\section{Literature Review}

There is a large literature on student academic performance and how it is influenced by innate ability, family, socioeconomic status, peers, neighborhoods, teachers, and schools. ${ }^{2}$ Among these factors, the influence of peers, especially black peers and peers from lower socioeconomic backgrounds, has been evaluated extensively. In general these papers provide evidence of peer effects although effects are typically small. Examples of papers documenting peer effects include Hoxby (2000), Evan et al (1992), Hanushek et al (2003), Ammermueller and Pischke

\footnotetext{
${ }^{2}$ See Todd and Wolpin (2003) for an early review of the literature. For a recent review of this literature see Bifulco et al (2011) and Diette and Uwaifo Oyelere (2013).
} 
(2006), Rumberger and Palardy (2005), Rivkin (2000), and Armor and Duck (2007). Within this literature of peer effects, a subgroup of studies have focused on potential heterogeneity in peer effects based on ethnicity, socioeconomic status, and gender. For example, Hanushek, Kain, and Rivkin (2009) find that among black students, having a higher percentage of Black schoolmates reduces achievement for blacks but not for white classmates. Angrist and Lang (2004) also find heterogeneous effects. They look at the effect of Metco, a program that sends students from Boston schools to more upper class suburban schools, on non-Metco students. Their findings suggest no effect on white students but modest effects on minority female students. Bifulco et al. (2011) finds that increases in the percent of classmates with college-educated mothers decreases the likelihood of dropping out and increases the likelihood of attending college.

Another subgroup that could potentially have negative effects given their socioeconomic status and English language limitations are immigrants. There is also a growing literature that considers the education effects of immigrants more generally while others studies focus specifically on immigrant peer effects on natives' achievement. For example, Hoxby (1998) and Borjas (2007) both look at whether immigrants crowd-out natives from slots in college and graduate programs. At the pre-college level, Betts and Fairlie (2003) provide some evidence of native flight to private schools in some metropolitan areas including Los Angeles and Santallino (2009) provides evidence of crowding out in North Carolina public schools. However, he does not find evidence of heterogeneity of this effect across race. Also more recently, Cascio and Lewis (2012) show that low-skilled immigration to the United States has contributed to a reduction of native demand for public schools.

Studies focused on the effect of immigrants on native students' achievement find conclusive trend. For example, Jensen and Rasmussen (2011), using data from Denmark, consider the short term impact of immigrant concentration in Denmark on natives' performance in math and reading and they note significant negative effects in math using an IV strategy. Similarly, Ohinata and Ours (2013) analyze how the share of immigrant children in the classroom affects the educational attainment of native Dutch children and note no significant effect in the short term. Both of these papers also test for heterogeneous effects of immigrant concentration by 
immigration status (natives versus immigrants) while we focus on possible heterogeneous effects among natives based on race and gender.

One paper finding no evidence of an immigrant peer effect is Geay, McNally, and Telhaj (2013). They examine the influence of non-native English speakers in England on reading, Writing and Mathematics exams at the end of primary school for native students in England. Gould, Lavy, and Paserman (2009), in contrast to the three aforementioned papers, examine the long-term academic effect of immigrant concentration in elementary school in Israel on passing a high school matriculation exam. Their results suggest negative effects of higher immigrant concentration in elementary school. A related paper focused on high school graduation is Betts (1998) who investigates whether immigrants affects the probability of high school graduation of American born minorities. His results suggest strong negative effects of immigrant concentration on African Americans and Hispanics, although the effects on Hispanics are not robust to the exclusion of California. His result provides further motivation to consider heterogonous racial effects of immigrant peers on natives. With respect to the U.S context, there are also a number of papers investigating immigrant peer effects within a state. For example, Conger (2012), using administrative data from Florida, suggests positive immigrant peer effects on high school achievement of natives and other immigrant students, a finding that contrasts with the previously mentioned papers focused on immigrant peer effects. ${ }^{3}$

Another indirect way of estimating immigrant peer effects is by focusing on the subset of immigrant students with limited English proficiency. One reason to concentrate on this subset of immigrants is that the specific channel is clear through which immigrants can negatively affect native students. Using different econometric approaches and covering different grades, Santillano (2009) and Diette and Uwaifo Oyelere (2013) both search for peer effects in North Carolina focused on this subset of immigrants. They both find significant heterogeneity in the effects of LE students on natives. The latter specifically notes negative effects on native students only at the top quartile of the achievement distribution. Cho (2012) also focuses on students with limited English proficiency, those classified as English Language Learners (ELL) in the U.S. She

\footnotetext{
${ }^{3}$ Also see Cortes (2006) who considers immigrant peer effects on immigrants in Miami and San Diego noting no significant effects.
} 
examines the effect of ELL students on academic achievement in math and reading for non-ELL students in kindergarten and first grade using a nationally representative sample. She finds negative effects for reading but not math when school fixed effects are included. She also finds that the negative effects are concentrated among females and those with low-family income and no effect on males or children from incomes above $\$ 25,000$.

One major difference between most of these earlier papers and this study is our focus on investigating possible racial and gender differences in the impact of immigrant peer effects. Cho (2012) also considers gender effects but with a different identification strategy and for younger children. Specifically, Cho (2012) makes use of school, grade and child fixed effects to identify the impact of exposure to ELL on test scores. This strategy has two potential limitations. First, exposure to ELL students as captured by the dummy variable does not allow for differences in impact based on the ELL student concentration which will provide a compelling pathway for how ELL students can affect native students. Second, child fixed effects can be affected by time varying omitted variables which could be correlated with a child's exposure to ELL students. Moreover with only two years of observations being considered by the author variation within the child might be limited, increasing the chances of incorrectly not rejecting the null hypothesis. Given the potential limitation of using individual level fixed effects we identify effects using school-year fixed effects and focus on the impact of ELL shares on native students' performance. Santillano (2009) is most closely linked with our paper because he searches for heterogeneous impacts across race and gender. Our paper differs from his paper in two important ways. First, we focus on 4th to 8th grade outcomes which create the opportunity to employ a school-year fixed effects while he focus solely on 4th and 5th grade using a matching estimator. Second, we divide the population of native students into achievement quartiles and search for heterogeneity in the effect across race and gender within each quartile.

\section{Data}

For this analysis we make use of administrative records created by the North Carolina Department of Public Instruction. This data is cleaned and maintained by the North Carolina Education Research Data Center (NCERDC) at Duke University. These data contain detailed and reliable information on both students and teachers. Student performance can also be tracked in a 
consistent way across school years. Students are required to take tests in Reading and Math at the end of each grade from third to eighth grade. ${ }^{4}$ The uniform exams given to students within a grade in a given year provides an opportunity to monitor relative student academic performance and track individual student's position within the distribution of students in their cohort over a significant amount of time. For our analyses we use data from 1998 to 2006. We select these years of data because they have consistent information on key variables across time. In particular the free lunch variable is a proxy for income level of a student's family and economic condition. This variable is not available in earlier years of data. Similarly, the variable Limited English is redefined in 2007. This change makes it more difficult to consistently identify LE students after 2006. In order to identify native students, the focus of our analysis, we only include students who have never been identified as LE at any point in their third through eighth grade career.

We define the share of LE students in their grade as the share of peers who are currently classified as LE. We measure LE shares at the grade level instead of the classroom level because classroom composition is endogenous. An investigation of possible peer effect of current LE students on native student performance is appropriate for testing the hypothesis that limited English proficiency is the potential mechanism for influencing native student academic achievement. A measure that defined LE students as those who have ever been classified LE would focus on peer effects of students with a different native language.

\section{Descriptive Statistics}

In Table 1 we summarize the mean and standard deviation of the share of LE students that native students have in their grade within their school as well as the mean z-score in both mathematics and reading. ${ }^{5}$ Panel A reports these means for all students, Panel B separates the students by gender and then by race, and Panel C looks individually at the four demographic groups of native students used in the study: Black females, White females, Black males, and White males.

\footnotetext{
${ }^{4}$ For additional details on North Carolina administrative data see Clotfelter, Ladd, Vigdor (2009).

${ }^{5}$ The z-scores were calculated using the entire student population who took the exams within the grade in that particular year. The mean z-score for Limited English students is below that of native students and therefore the mean z-score for students in our analysis is greater than zero.
} 
$<<$ Insert Table $1>>$

On average, Limited English students represent 2.7 percent of the peers for native students in North Carolina (Panel A). While there are no differences in the peer composition by gender, black students have a slightly higher average share of LE students in their grades in their school than their White counterparts, 3.2 percent compared to 2.5 percent. In Panel B, we find that boys and girls have similar average z-scores in math, but girls outperform boys by 0.15 of a standard deviation in reading. In addition in Panel C, we report the significant black-white achievement gap that exists in North Carolina public schools for both genders.

$<<$ Insert Table $2>>$

Table 2 summarizes the distribution of students by race and gender within the math and reading z-score distribution. Among black students, over half of males and females are in the bottom third of z-scores in both math and reading. In contrast over 45 percent of white students are in the top third in both math and reading. These statistics highlight the importance of disentangling the potential effect of LE students on native students of different racial groups from the effect of LE students on native students at different points in the achievement distribution.

$<<$ Insert Table 3>>

Table 3 reports the share of Limited English students by demographic group within the achievement distribution. Within each demographic group, larger shares of LE students are associated with the students in the bottom third of the achievement distribution. For example in reading, black males in the top third of the achievement distribution have an average of 3.0 percent LE students within their grade in their school. This share rises modestly to 3.2 percent for black males in the bottom third of the achievement distribution. Across demographic groups, we see that White students in the bottom third of the achievement distribution have a lower average share of LE students in their grade than black students in the top third of the achievement distribution. 


\section{Methodology}

We have two primary questions of interest. Do significant LES shares in a school create heterogeneous effects on the academic performance of native students by gender and do blackwhite differences exist in the impact of significant immigrant presence in a school? Second, are the effects of race and gender, if any, distributed evenly among subpopulations (i.e females, males, black students, and white students) by achievement ranking? We address these related questions first using a basic value added model estimated by ordinary least squares (OLS) separately for girls and boys and also separately by black and white. In our OLS estimation, we control for the share of limited English students in the grade, previous achievement of the student in the same subject, parent education level, race/ethnicity (in the gender estimations), year fixed effects, grade fixed effects, and eligibility for free lunch and reduced price free lunch, a proxy for family's economic status.

We then introduce controls for peers, given the broad literature on peer effects, using the racial composition of peers and share of students eligible for free lunch and reduced priced price. Subsequently, we further control for school related variables that could also potentially affect students' performance and are correlated with immigrant exposure including the pupil teacher ratio, status as a charter or magnet school, school level free and reduced price lunch eligibility, and urbanicity of the school. Next, we include teacher level controls. Equation 1 highlights our basic specification with all the controls highlighted above which we estimate separately for girls and boys, black students and white students and compare for statistical difference.

$$
\text { (equation 1) } \quad Z_{\text {igst }}=\beta_{0}+\gamma Z_{i(t-1)}+\beta_{1} L E_{g s t}+\delta X_{i g s t}+\mu T_{s t}+\delta S_{s g t}+\varepsilon_{i g s t}
$$

In equation $1 Z_{\text {igst }}$ is the $\mathrm{z}$-score in math or reading for student $\mathrm{i}$ in grade $\mathrm{g}$ and school $\mathrm{s}$ in time period t. $L E_{g s t}$ is the LE students' share of the student population in grade $g$ in school s in time period t. $\mathrm{X}$ is a matrix of individual characteristics and $\mathrm{T}$ is the matrix of observable teacher variables that affect achievement. $S$ is a vector of school related variables that could affect 
achievement. $Z_{i(t-1)}$ captures an individual's achievement in period t-1. In the standard valueadded model this variable characterizes the knowledge or skills students have at entry to a grade and are affected by prior family, neighborhood, school experience and individual's ability.

The estimated LE peer effect using equation 1 is likely to be biased as families self-select into schools based on different factors including educational preferences and ability of a child. Hence we are still worried about potential unobservable characteristics that are correlated with our control variables and our variable of interest but may also determine students achievement $i$. To address this potential problem in our analysis, we make use of two alternative approaches. In each of these approaches we analyze panel data from North Carolina public schools to estimate the impact of LE shares. The first approach is to estimate equation 1 including school level fixed effects. This specification will help us address the non-random selection into schools and hence control for unobserved school attributes that correlate with grade-level immigrant shares. This technique has been used frequently in the literature but could still potentially create biased estimates of our variable of interest in an analysis combining data over time. This will occur if there are time varying unobservables within a school that are correlated with LE shares and also students' achievements. Our second approach deals with this problem. We estimate an equation similar to equation 1 but including school-by-year fixed effects (see equation 2). Where $\alpha_{s t}$ is a school by year fixed effect.

(equation 2) $Z_{i g s t}=\beta_{0}+\gamma Z_{i(t-1)}+\beta_{1} I_{i g s t}+\delta X_{i g s t}+\mu T_{i g s t}+\delta S_{i g s t}+\alpha_{s}+\varepsilon_{i s t}$

This approach allows us to identify the impact of LE share on natives' achievement because even though the total number of LE in a school at a particular time is non-random, within the school, the number of LE in a specific grade at time $t$ is due to random factors, such that endogeneity is overcome by identifying impacts across grades within a particular point in time.

Diette and Uwaifo Oyelere (2012) only find evidence of a LE peer effect on native students within the top quartile of the achievement distribution in North Carolina public schools. However, our second question considers possible peer effects across all the achievement distribution due to the possibility of heterogeneous effects across the groups. By dividing the 
achievement distribution into thirds (top third, middle third bottom third). Running different regressions by level of achievement is especially important because the quality of education may vary systematically by achievement level within schools given the prevalence of tracking systems in many public schools in the U.S. Moreover by looking at these subgroups, we can avoid constraining the school, year and grade fixed effects for these various groups to be equal. In each model the standard errors are corrected for heteroskedasticity.

There are other estimation approaches that have been used in the past literature to deal with the potential endogeneity in the variable of interest such as including individual level fixed effects or including school by grade fixed effects. These approaches, though sometimes preferred to a simple OLS regression, could still potentially lead to biased estimates and estimates of LE peer effects using these methods are not presented in this paper. ${ }^{6}$ Diette and Uwaifo Oyelere (2013) detail some of the challenges with these other estimation approaches. Hence, we present only the value-added approach with school fixed effects and our preferred model of the school-by-year fixed effect. Our primary interest in our analysis is in if the estimates of $\beta_{1}$ for female, male, black and white native students are statistically different. We also interested in the intersection of race and gender effects. Specifically if $\beta_{1}$ for black females, white females, black males and white male are statistically different from each other.

\section{Results}

\subsection{Results by Gender}

\section{[insert Table 4: here]}

Table 4 summarizes the results for girls of our base specification as well as the models with initial additional controls for math and reading. Table 5 summarizes our results for boys. To keep the focus on our variables of interest and to manage the length of our table, we display only the non-dummy variable coefficients in Table 4 and 5 and note the other controls we use in each model at the bottom of each of these tables. ${ }^{7}$ In each of the specifications in Table 4 columns (1)

\footnotetext{
${ }^{6}$ Results using individual fixed effects and school by grade fixed effects specifications are available on request.

${ }^{7}$ Full regression output showing all coefficient estimates are available on request.
} 
to (4), a student's math z-scores for the current year is our dependent variable while in columns (5)- (8) the dependent variables is a student's reading z-score. The coefficients summarized in columns (1)-(8) of Table 4 and 5 are estimated using OLS. Due to our concerns of endogeneity and selection bias we do not make casual inferences from these results. In contrast we showcase these results as a baseline for comparison to our results in subsequent tables using our preferred estimator. For the results summarized in column (1) our reference model, we control for parent's education using parent education dummies. These variables capture whether a student's parent dropped out of high school dropout, graduated high school graduate, has some college, earned a bachelor's degree, or completed an advanced degree. We also control for if a child has ever been on the free lunch program and if a child has ever been on the reduced lunch program. ${ }^{8}$

\section{[Insert Table 5: here]}

The results in columns (1) to (8) of Table 4 suggest a negative relationship between exposure to LE students and a girl's math and reading Z scores. The additional controls in columns (2) to (4) and (6) to (8) do not change the size of the coefficient significantly. In columns (2) and (6) we control for possible racial and ethnic peer effects by including the share of students within the student's cohort who are classified in the NC schools as Black, Latino, and Asian. We also include for each student the share of their cohort in that year who participate in the free lunch program and those who participate in the reduced price lunch program. In columns (3) and (7) we add school level characteristics. We include dummies for if a school is a charter school or magnet school. We also control for the percent of the students in a school that are eligible for free or reduced price lunches in each given time period and the teacher pupil ratios which could proxy for class size, a measure of school quality. Given the potential importance of school location for education outcomes, we include dummies for location (city, town, and rural with suburb as the reference group).

\footnotetext{
${ }^{8}$ We do not use the yearly response of students to the question of if they are using the free lunch or reduced lunch program given the noted trend that older kids may not want to reveal they are on this program because of the potential stigma. We use these variables to capture family income levels which are also potentially important variables that affect achievement.
} 
In column (4) and (8) we control for teacher characteristics in a manner similar to Diette and Uwaifo Oyelere (2012). Specifically we include the average number of teachers in a school that are female that year, the average number of teachers in a school in their first year of teaching. We also control for the ethnicity of teachers using dummies that capture the average number of teachers by ethnicity. To control for teacher quality, we include the number of teachers with a master's degree in a school at a given time period and also a control for the average test scores of teachers in a school at a given point in time.

The results in Table 5 suggest that there is no relationship between LES shares and boys performance in either math or reading. The coefficient of interest is only significant in the base model for reading. However as previously highlighted, the result in Table 4 and 5 could be biased given the use of an OLS regression framework without controlling for potential endogeneity of our variable of interest and possible bias arising from selection of students across schools. Hence these preliminary results do not allow us make deductions about the causal effect of LE student shares on performance for boys and girls in math and reading. The first method we explore to deal with the possible bias in the OLS estimates is to introduce school level fixed effects. The advantage of using school level fixed effects is that it allows us to estimate impacts based on within school differences versus differences across schools. Therefore our within school variation comes from variation in exposure across grades and across time. ${ }^{9}$ The estimated impact of LE students on natives using school level fixed effects are summarized in Table 6. The results for math are in column (1) and the results for reading are in column (3). Panel A summarizes the results for girls and Panel B the results for boys.

The results including school fixed effects are similar to the results in Table 4 and 5. They suggest negative impacts of LE students on girls and no significant impacts on boys. Can we conclude that there are causal impacts with this specification? No. As mentioned above, though a school level fixed effect can deal with a substantial part of the possible bias in our coefficient of interest, $\beta_{1}$, it is still possible that if we look within schools over time, there may be time-varying unobservables that are correlated with immigrant share and also affect achievement. Our second

\footnotetext{
${ }^{9}$ We also control for variation across grade and time across schools'
} 
and preferred approach introduces school by year fixed effects which deals with these kinds of issues. One weakness common to this method is the loss of variation given the inclusion of a within school and year fixed effect. This could lead to large standard errors and loss of significance. The advantage with this specification is that it eliminates most plausible kinds of selection and causal impacts can be inferred. The only possible type of selection that it cannot deal with is if there is selection across grades within a school. It is hard to tell a story of selection across grades at a given period in time but we cannot rule it out entirely.

\section{$<<$ Insert Table 6>>}

The estimates including school-by-year fixed effects for boys and girls are summarized in columns (2) and (4) of Table 6. The results are the reverse of what the earlier models suggest and reinforce the need to control for potential time varying unobservables. First we find that there is no significant impact of LE student shares on females' reading and math scores but a significant impact exists for males although the magnitude is small. Specifically, an increase in LE shares by one percentage point leads to a decline in male students math $\mathrm{Z}$ scores by 0.00074 standard deviation and a decline in reading scores by 0.00072 .

The results suggest significant heterogeneity across gender in the impact of LES shares. One possible reason for this result is past research suggesting boys on average do not work as hard as girls in school (Warrington 2013). ${ }^{10}$ In this scenario the potential reduction in human capital transfer to native students that might take place in a class where the teacher has to devote more time to LE students might be balanced out by the increase in personal effort by girls but not for boys assuming they do not work as hard. This then leads to a slight decline in performance for boys. This finding is consistent with Taylor and Wong, (1996) who find that boys' grades are more strongly affected by peer orientation than girls. On the other hand, Legewie and Di Prete (2012) use data from Germany to provide another plausible explanation for negative peer effects on boys. They argue that boys are more sensitive than girls to school resources that create a learning-oriented environment and socioeconomic status composition in a student's school is a

\footnotetext{
${ }^{10}$ Also see Flannery (March 5, 2013) op-ed in NEA today, "Why Girls Are Outperforming Boys in School.”
} 
significant learning resource. Their argument for why socioeconomic status composition matters is based on the premise that level of motivation and capability within the classroom are learning resources which are correlated with higher socioeconomic status of students. Their empirical analysis provides evidence that lower social economic composition leads to worse achievement outcomes for boy than girls. Their finding is a good explanation for our results given the increase in the LE student shares in schools in North Carolina led to a decline in the socioeconomic status composition, which according to their model would affect boys' academic achievement more severely than girls and is reflected in the negative peer effects we note solely for boys. Next we search for heterogeneity in the impact of LE students across blacks and whites.

\subsection{Heterogeneity Across Race}

We approach the question of if heterogeneity exists across race in the impact of LES shares the same way we approached gender differences. Table 7 summarizes the preliminary regressions without relevant fixed effects for blacks while Table 8 is a summary of the results for whites. The results of these preliminary analyses are mixed. However, the results summarized in column (4) and (8) of Table 7 and 8 seem to suggest a negative relationship between LES shares and performance in math for blacks and we also note a negative relationship for whites in reading. However this result is biased and we do not make causal inferences as with the results in Table 4 and 5. To be able to make any casual inference we turn to our models estimated with fixed effects. The results using school fixed effects and school-by-year fixed effects are summarized in Table 9. The results in columns (1) and (3) including only school fixed effects suggests negative effects of LE students shares on both black and white in reading and math. Given the similarity of the estimates for black and white, this result though likely to be biased suggests no heterogeneity in the LES effect across race.

$<<$ Insert Table 9>>

Our preferred model the school by year fixed effect is summarized in columns (2) and (4) of Table 9. It suggests on average no LE student peer effect on whites' achievement in either reading or math and a significant negative LE students peer effect on black achievement in both reading and math. 
Insert [Table 10: ] here

[Table 10]

The above results using school-by-year fixed effects provide evidence of heterogeneity across gender and across race. We reestimate the model testing for LES peer effects dividing the population into 4 subgroups by gender and race: Specifically we divide the population into black female, white female, black male, white male.

Table 10 summarizes the estimated LES effect using both the school fixed effect and the school by year fixed effect estimates. The first two columns summarize the results for math and the last two for reading. Though all the estimated effects are negative, most are not significant. Specifically we find that on average there are no LES peer effects on girls whether or not they are black or white. In contrast we find negative peer effects on White males in math and negative peer effects for black males in both reading and math. ${ }^{11}$

Noting racial heterogeneity in the effect of peer effects is not new. Hanushek, Kain and Rivikin (2009) find negative effects on achievement for blacks of having more black peers in Texas while noting no effect on whites of having more black peers. A similar finding was made by Angrist and Lang (2004) when looking at the impact of Metco on students in the receiving districts. They find little evidence that white students are affected but black students appear more sensitive to this change. These authors provide various possible explanation for these finding drawing on the literature suggesting behavioral, social and peer culture differences and the "acting white" phenomena (see Fryer (2006) and (2010) for a discussion of some of these views).. However, finding negative effects on whites and blacks at the top of the achievement distribution suggests that behavioral explanations do not suffice and possible teacher resource constraint effects may be relevant. Meaning that the share of LE students may lead to teachers being forced to focus more on the low performing students and less on the students at the top in schools. Also our results suggest the need to go beyond looking at just average effects when investigating peer effects. Notice that if we did not look within the achievement distribution, our conclusion would have been that LE students have no effect on white native students but they do.

\footnotetext{
${ }^{11}$ The coefficient for black males in math is approximately significant at the $10 \%$ level.
} 


\subsection{Heterogeneity within the Achievement Distribution}

The importance of looking for potential differences in impact within the achievement distribution was highlighted by Diette and Uwaifo Oyelere (2012). To test for such differences we divide both male and female students into 3 groups based on performance in math and reading: the top third\%, the middle third and the bottom third of the achievement distribution. We then estimate our value added model with school-by-year fixed effect for each group. Table 11 and 12 provides the estimate of the impact of LES shares on the various groups. In Table 11 we summarize the results for black students and in Table 12 we summarize the results for white students. In columns (1) and (4) the estimate on the impact of LE student on the top 33.33\% of the distribution are summarized.in columns (2) and (5) the middle 33.33\% and in columns (3) and (6) the bottom third.

Insert [Table 11: ] here

The results reveal the importance of looking within the achievement distribution. Although must of the estimated effects are negative in Table 11, a few of the estimated effects are positive in Table 12 but not significant. Overall we see some similarities to Diette and Uwaifo Oyelere (2013) but our analysis breaking down the population by race and gender does not suggest that all negative peer effects can be found on top. We however find evidence that LES shares has no effect on children in the bottom third of the achievement distribution regardless of gender and race. We also find that achievement of white girls are not affected by increases in LES shares whereas increases in LES shares affect black girls in the middle of the achievement distribution negatively but has no effect on black girls at the top or bottom third in both reading and math . We also find effects for both black males and white males. Specifically we find effects for black males in reading in the middle and top third of the distribution and for white males we find negative effects at the top of the achievement distribution in math and at the top and middle third in reading. These effects are of higher magnitude than the impacts estimated when we do not break down the population by achievement levels.

Insert [Table 12: ] here 
[Table 12:]

The above results suggest heterogeneity across gender and race in the impact of LE shares on native students' achievement. Although the magnitude of the coefficients when we focus on black males, black females and white males seems large, keep in mind these are the effects with a unit change in the share of LES students which is a huge change. Typically based on our results above, an increase in LES shares say by 1 percentage point will lead to a decline in performance of black males in reading by 0.00257 of a standard deviation which is not a decline that policy makers in education should be really concerned with.

\section{Inferences, Summary and Conclusions}

In this paper we focus on two basic questions: First, do significant increases in LE students into a school affect the academic performance of native boys and girls differently? Second, do increases in limited English create similar effects on academic achievement of blacks and whites? These questions are important given the possible differential effects increases in LES shares could have within the population.

Given the potential endogeneity of our variable of interest to infer casual effects, we include school - by- year fixed effects. Our findings show that LE student shares have no effect on white girls performance in math and reading but has a significant negative effect on test performance on white native males in the top third of the achievement distribution in math and both the top third and middle thirds in reading. We also find negative effects on black females in the middle third of the achievement distribution in both reading and math and for black males negative LES peer effects are noted in the top and middle thirds for reading.

Why are these results important? First, these results provide some evidence that increased exposure to LE students do create peer effects and these effects are not homogenous within the 
population. Our results suggest boys regardless of race are affected negatively by LE student shares though effect is not substantial. In contrast we find heterogeneity in effect among girls with negative effects among black girls and none among white girls. Our finding is in contrast to Angrist and Lang, (2004) who find negative peer effects on girls but not boys from the METCO program in Massachusetts. This differences in who is impacted by increased exposure to disadvantaged peers underscores the need not to generalize findings for North Carolina to other states. Further, the presence of heterogeneous effects in our study provides evidence in support of looking for peer effects across race, gender and achievement level. Our results are also important as they highlight the importance of controlling for across school unobservables and possible within school unobservables over time. Estimates not accounting for these unobservables and potential selectivity bias, as reflected in our results can be significantly biased even with the inclusion of a decent number of controls.

It is important to mention again that our results could potentially have some limitations. Our school -by-year fixed effect specification is assuming that there is no selection across grades within a school at a given point in time. Such an assumption though consistent with what we know about North Carolina and the public school stem in the U.S in general, may not always be valid. We hope to focus future work on estimating the effect of LE students' shares increases on teacher retention. 


\section{References}

Ammermueller, Andreas, and Jörn-Steffen Pischke. 2006. Peer effects in European primary schools: Evidence from PIRLS. No. w12180. National bureau of economic research,.

Angrist, Joshua D., and Kevin Lang. 2004. Does school integration generate peer effects? Evidence from Boston's Metco Program. The American Economic Review 94.5 : 1613-1634.

Armor, David, and Stephanie Duck. 2007. Unraveling Black Peer Effects on Black Test Scores. unpublished manuscript.

Betts, Julian R., 1998, Educational Crowding Out: Do Immigrants Affect the Educational Attainment of American Minorities?, in Daniel S. Hamermesh and Frank D. Bean (Eds.), Help or Hindrance? The Economic Implications of Immigration for African-Americans, New York: Russell Sage Foundation.

Betts, Julian.R. and Fairlie, Robert.W. 2003. Does immigration induce native flight from public schools into private schools, Journal of Public Economics, vol. 87(5-6) (May), pp. 987-1012.

Bifulco, Robert, Jason M. Fletcher, and Stephen L. Ross. 2011. The Effect of Classmate Characteristics on Post-Secondary Outcomes: Evidence from the AddHealth. American Economic Journal: Economic Policy 3: 25-53.

Borjas, George J. 2007. Do foreign students crowd out native students from graduate programs?, in (P.E. Stephan and R.G. Ehrenberg, eds.), Science and the University, pp. 134-49, Madison, WI: University of Wisconsin Press.

Clotfelter, Charles T. \& Ladd, Helen F. \& Vigdor, Jacob L., 2007. Teacher credentials and student achievement: Longitudinal analysis with student fixed effects, Economics of Education Review, Elsevier, vol. 26(6), pages 673-682, December .

Cho, Rosa Minhyo. 2012. Are there peer effects associated with having English Language Learner (ELL) classmates? Evidence from the Early Childhood Longitudinal Study Kindergarten Cohort (ECLS-K). Economics Of Education Review, 31(5), 629-643.

Conger, Dylan. 2012. Immigrant peers and academic performance in high school. George Washington University Working Paper, 2012.

Cortes, Kalena. 2006. The Effects of Age at Arrival and Enclave Schools on the Academic Performance of Immigrant Children.” Economics of Education Review 25(2): 121-132.

Diette Tim and Ruth Uwaifo Oyelere. 2012. Do Significant Immigrant Inflows Create Negative Education Impacts? Lessons from the North Carolina Public School System. IZA working paper No 6561. 
Ehrenberg, Ronald G., and Dominic J. Brewer.., 1994. Do school and teacher characteristics matter? Evidence from high school and beyond. Economics of Education Review 13, 1-17.

Fryer Roland G 2010. An Empirical Analysis of 'Acting White', Journal of Public Economics. Volume 94, Issues 5-6, June 2010, Pages 380-396

Fryer Roland G. 2006. Acting White' the social price for the best and brightest minorities, Education Next, Vol 6. No 1 pp52-59.

Gould, Eric D., Victor Lavy, and M. Daniele Paserman. 2009. Does Immigration Affect the Long-Term Educational Outcomes of Natives? Quasi-Experimental Evidence. Economic Journal, Royal Economic Society, vol. 119(540), pages 1243-1269.

Hanushek, Eric A., John F. Kain, Jacob M. Markman, S.G. 2003. Does peer ability affect student achievement?, Journal of Applied Econometrics, vol. 18(5), (September/October), pp. 527-44.

Hanushek \& Rivkin 2009. Harming the Best: How Schools Affect the Black-White Achievement Gap," Journal of Policy Analysis and Management, Vol. 28, No. 3, 366-393.

Hanushek, Eric A., John F. Kain and Steven G. Rivkin. 2009. New evidence about Brown v. Board of Education: The complex effects of school racial composition on achievement. Journal of Labor Economics 27, 3.

Hoxby, Caroline M. 1998. Do immigrants crowd disadvantaged American natives out of higher education?, in (D.S. Hamermesh and F.D. Bean, eds.), Help or Hindrance? The Economic Implications of Immigration for African Americans, New York: Russell Sage Foundation,.

Hoxby, Caroline M. 2000. Peer effects in the classroom: learning from gender and race variation, NBER Working Paper No. 7867.

Lavy, Victor and Analia Schlosser. 2011. Mechanisms and Impacts of Gender Peer Effects at School, American Economic Journal: Applied Economics. American Economic Association, vol. 3(2), pages 1-33, April.

Legewie Joscha and Thomas A. DiPrete. 2012. School Context and the Gender Gap in Educational Achievement. American Sociological Review June 2012 77: 463-485, first published on April 4, 2012.

Rivkin. Steven G. 2000. School Desegregation, Academic achievement, and Earnings. Journal of Human Resources (2): 333-346.

Rumberger, R. W. \& Palardy, G. J. 2005. Does segregation still matter? The impact of social composition on academic achievement in high school. Teachers College Record, 107, 19992045. 
Santillano, Robert. 2009. Essays on Immigrant Students in Public Schools-Evidence from North Carolina. Ph.D., University of California, Berkeley, 146 pp.

Taylor, Erika.D., \& Wong, Carol.A. 1996. Gender differences in the impact of peer influences and peer orientation on African-American adolescents' school value and academic achievement. Poster session at the sixth biennial meeting of the Society for Research on Adolescence, Boston, MA.

Todd, Petra and Kenneth I. Wolpin. 2003. On the Specification and Estimation of the Production Function for Cognitive Achievement. The Economic Journal, Vol. 113, No. 485, F3-33.

Warrington M, M, Younger and J Williams 2013. Student Attitudes, Image and the Gender Gap, British Educational Research Journal Volume 26, Issue 3. 


\section{Tables}

Table 1: Exposure to Limited English Students and Average Test Scores

\begin{tabular}{|c|c|c|c|c|c|c|c|}
\hline & \multirow[t]{2}{*}{ Number } & \multicolumn{2}{|c|}{$\begin{array}{l}\text { Avg share of limited } \\
\text { English }\end{array}$} & \multicolumn{2}{|c|}{ Avg z-score math } & \multicolumn{2}{|c|}{ Avg z-score reading } \\
\hline & & Mean & Std. Dev. & Mean & Std. Dev. & Mean & Std. Dev. \\
\hline $\begin{array}{l}\text { Panel A } \\
\text { All }\end{array}$ & $3,094,280$ & 0.0274 & (0.0395) & 0.0621 & (0.9872) & 0.0637 & (0.9739) \\
\hline Panel B & & & & & & & \\
\hline Girls & $1,543,554$ & 0.0273 & (0.0394) & 0.0734 & (0.9553) & 0.1445 & (0.9318) \\
\hline Boys & $1,550,726$ & 0.0274 & (0.0395) & 0.0508 & (1.0178) & -0.0169 & (1.0077) \\
\hline Black & 939,173 & 0.0315 & $(0.0451)$ & -0.4867 & $(0.8428)$ & -0.4510 & (0.9044) \\
\hline White & $1,983,408$ & 0.0248 & $(0.0354)$ & 0.3144 & $(0.9452)$ & 0.3034 & $(0.9135)$ \\
\hline Panel C & & & & & & & \\
\hline Black Girls & 478,613 & 0.0314 & $(0.0450)$ & -0.4326 & $(0.8274)$ & -0.3378 & $(0.8654)$ \\
\hline White Girls & 978,221 & 0.0247 & $(0.0352)$ & 0.3138 & $(0.9172)$ & 0.3771 & $(0.8748)$ \\
\hline Black Boys & 460,560 & 0.0316 & $(0.0453)$ & -0.5429 & $(0.8548)$ & -0.5694 & (0.9287) \\
\hline White Boys & $1,005,187$ & 0.0248 & $(0.0355)$ & 0.3149 & $(0.9717)$ & 0.2315 & $(0.9443)$ \\
\hline
\end{tabular}

Table 2: Distribution of Demographic Groups by Achievement

\begin{tabular}{|c|c|c|c|c|}
\hline \multicolumn{5}{|c|}{$\begin{array}{c}\text { Panel A } \\
\text { By Mathematics Score }\end{array}$} \\
\hline & Top third & Middle third & Bottom third & Total \\
\hline Black Girls & $15.8 \%$ & $30.9 \%$ & $53.3 \%$ & $100 \%$ \\
\hline White Girls & $46.2 \%$ & $31.4 \%$ & $22.4 \%$ & $100 \%$ \\
\hline Black Boys & $13.8 \%$ & $27.7 \%$ & $58.5 \%$ & $100 \%$ \\
\hline White Boys & $47.0 \%$ & $29.3 \%$ & $23.7 \%$ & $100 \%$ \\
\hline \multicolumn{5}{|c|}{$\begin{array}{c}\text { Panel B } \\
\text { By Reading Score }\end{array}$} \\
\hline & Top third & Middle third & Bottom third & Total \\
\hline Black Girls & $19.6 \%$ & $35.9 \%$ & $44.6 \%$ & $100 \%$ \\
\hline White Girls & $51.4 \%$ & $31.5 \%$ & $17.1 \%$ & $100 \%$ \\
\hline Black Boys & $15.1 \%$ & $30.8 \%$ & $54.1 \%$ & $100 \%$ \\
\hline White Boys & $46.4 \%$ & $31.4 \%$ & $22.1 \%$ & $100 \%$ \\
\hline
\end{tabular}


Table 3: Average Share Limited English Students by Demographic Groups and Achievement

\begin{tabular}{|c|c|c|c|c|}
\hline \multicolumn{5}{|c|}{$\begin{array}{c}\text { Panel A } \\
\text { By Mathematics Score }\end{array}$} \\
\hline & Top third & Middle third & Bottom third & Total \\
\hline Black Girls & 0.0302 & 0.0307 & 0.0322 & 0.0314 \\
\hline White Girls & 0.0245 & 0.0245 & 0.0256 & 0.0247 \\
\hline Black Boys & 0.0305 & 0.0311 & 0.0321 & 0.0316 \\
\hline White Boys & 0.0245 & 0.0247 & 0.0257 & 0.0248 \\
\hline \multicolumn{5}{|c|}{$\begin{array}{c}\text { Panel B } \\
\text { By Reading Score }\end{array}$} \\
\hline & Top third & Middle third & Bottom third & Total \\
\hline Black Girls & 0.0301 & 0.031 & 0.0323 & 0.0314 \\
\hline White Girls & 0.0244 & 0.0246 & 0.0259 & 0.0247 \\
\hline Black Boys & 0.0302 & 0.031 & 0.0324 & 0.0316 \\
\hline White Boys & 0.0244 & 0.0247 & 0.0258 & 0.0248 \\
\hline
\end{tabular}


Table 4: Preliminary Regressions for Girls Math and Reading

\begin{tabular}{|c|c|c|c|c|c|c|c|c|}
\hline \multirow[b]{2}{*}{ VARIABLES } & \multicolumn{4}{|c|}{ Math } & \multicolumn{4}{|c|}{ Reading } \\
\hline & $\begin{array}{c}\text { Base } \\
(1)\end{array}$ & $\begin{array}{c}\text { Plus Peers } \\
(2)\end{array}$ & $\begin{array}{c}\text { Plus School } \\
(3)\end{array}$ & $\begin{array}{c}\text { Plus Teacher } \\
(4)\end{array}$ & $\begin{array}{c}\text { Base } \\
\text { (5) }\end{array}$ & $\begin{array}{c}\text { Plus } \\
\text { Peers } \\
(6) \\
\end{array}$ & $\begin{array}{c}\text { Plus } \\
\text { School } \\
(7)\end{array}$ & $\begin{array}{c}\text { Plus Teacher } \\
(8)\end{array}$ \\
\hline Previous Year Reading Z-Score & $\begin{array}{c}0.802^{* * * *} \\
(0.001)\end{array}$ & $\begin{array}{c}0.801^{* * *} \\
(0.001)\end{array}$ & $\begin{array}{c}0.801^{* * *} \\
(0.001)\end{array}$ & $\begin{array}{c}0.801^{* * *} \\
(0.001)\end{array}$ & $\begin{array}{c}0.752 * * * \\
(0.001) \\
-\end{array}$ & $\begin{array}{c}0.752 * * * \\
(0.001)\end{array}$ & $\begin{array}{c}.751 * * * \\
(0.001)\end{array}$ & $\begin{array}{c}0.751^{* * *} \\
(0.001)\end{array}$ \\
\hline Share of Limited English & $\begin{array}{l}-0.015 \\
(0.010)\end{array}$ & $\begin{array}{c}-0.036 * * * \\
(0.012)\end{array}$ & $\begin{array}{c}-0.028 * * \\
(0.012)\end{array}$ & $\begin{array}{c}-0.036 * * * \\
(0.012)\end{array}$ & $\begin{array}{c}0.044^{* * *} \\
(0.011)\end{array}$ & $\begin{array}{c}-0.033 * * \\
(0.013)\end{array}$ & $\begin{array}{c}-0.029 * * \\
(0.013)\end{array}$ & $\begin{array}{c}-0.033 * * \\
(0.013)\end{array}$ \\
\hline Pupil Teacher ratio & & & $\begin{array}{c}-0.0004 * * * \\
(0.000)\end{array}$ & $\begin{array}{c}-0.0003^{* * *} \\
(0.000)\end{array}$ & & & $\begin{array}{c}-0.0007 * * * \\
(0.000)\end{array}$ & $\begin{array}{c}-0.0005^{* * *} \\
(0.000)\end{array}$ \\
\hline Magnet School & & & $\begin{array}{c}-0.007 * * * \\
(0.002)\end{array}$ & $\begin{array}{c}-0.005^{* * *} \\
(0.002)\end{array}$ & & & $\begin{array}{c}0.004^{* *} \\
(0.002)\end{array}$ & $\begin{array}{c}0.005^{* * *} \\
(0.002)\end{array}$ \\
\hline Charter School & & & $\begin{array}{c}-0.074^{* * *} \\
(0.008)\end{array}$ & $\begin{array}{c}-0.037 * * * \\
(0.008)\end{array}$ & & & $\begin{array}{c}-0.032 * * * \\
(0.009)\end{array}$ & $\begin{array}{l}-0.008 \\
(0.009)\end{array}$ \\
\hline Average no female teachers & & & & $\begin{array}{c}0.235^{* * * *} \\
(0.007)\end{array}$ & & & & $\begin{array}{c}0.149 * * * \\
(0.007)\end{array}$ \\
\hline Average no first year teachers & & & & $\begin{array}{c}-0.141^{* * *} \\
(0.012)\end{array}$ & & & & $\begin{array}{c}-0.167^{* * *} \\
(0.013)\end{array}$ \\
\hline Average no teacher with masters & & & & $\begin{array}{c}0.033 * * * \\
(0.005)\end{array}$ & & & & $\begin{array}{c}0.017 * * * \\
(0.006)\end{array}$ \\
\hline Teacher test mean & & & & $\begin{array}{c}0.001 \\
(0.003)\end{array}$ & & & & $\begin{array}{c}0.0148^{* * *} \\
(0.003)\end{array}$ \\
\hline \multicolumn{9}{|l|}{ ADDITIONAL CONTROLS } \\
\hline Share of students by race dummies & No & Yes & Yes & Yes & No & Yes & Yes & Yes \\
\hline Share of free lunch students & No & Yes & Yes & Yes & No & Yes & Yes & Yes \\
\hline Share of pupils on reduced lunch & No & Yes & Yes & Yes & No & Yes & Yes & Yes \\
\hline School location Dummies & No & No & Yes & Yes & No & No & Yes & Yes \\
\hline$\%$ of school free/reduced lunch & No & No & Yes & Yes & No & No & Yes & Yes \\
\hline Average Teacher race dummies & No & No & No & Yes & No & No & No & Yes \\
\hline Observations & 1543554 & 1543554 & 1543554 & 1543554 & 1539292 & 1539292 & 1539292 & 1539292 \\
\hline R-squared & 0.741 & 0.742 & 0.742 & 0.742 & 0.684 & 0.684 & 0.684 & 0.685 \\
\hline
\end{tabular}


Table 5: Preliminary Regressions for Boys Math and Reading

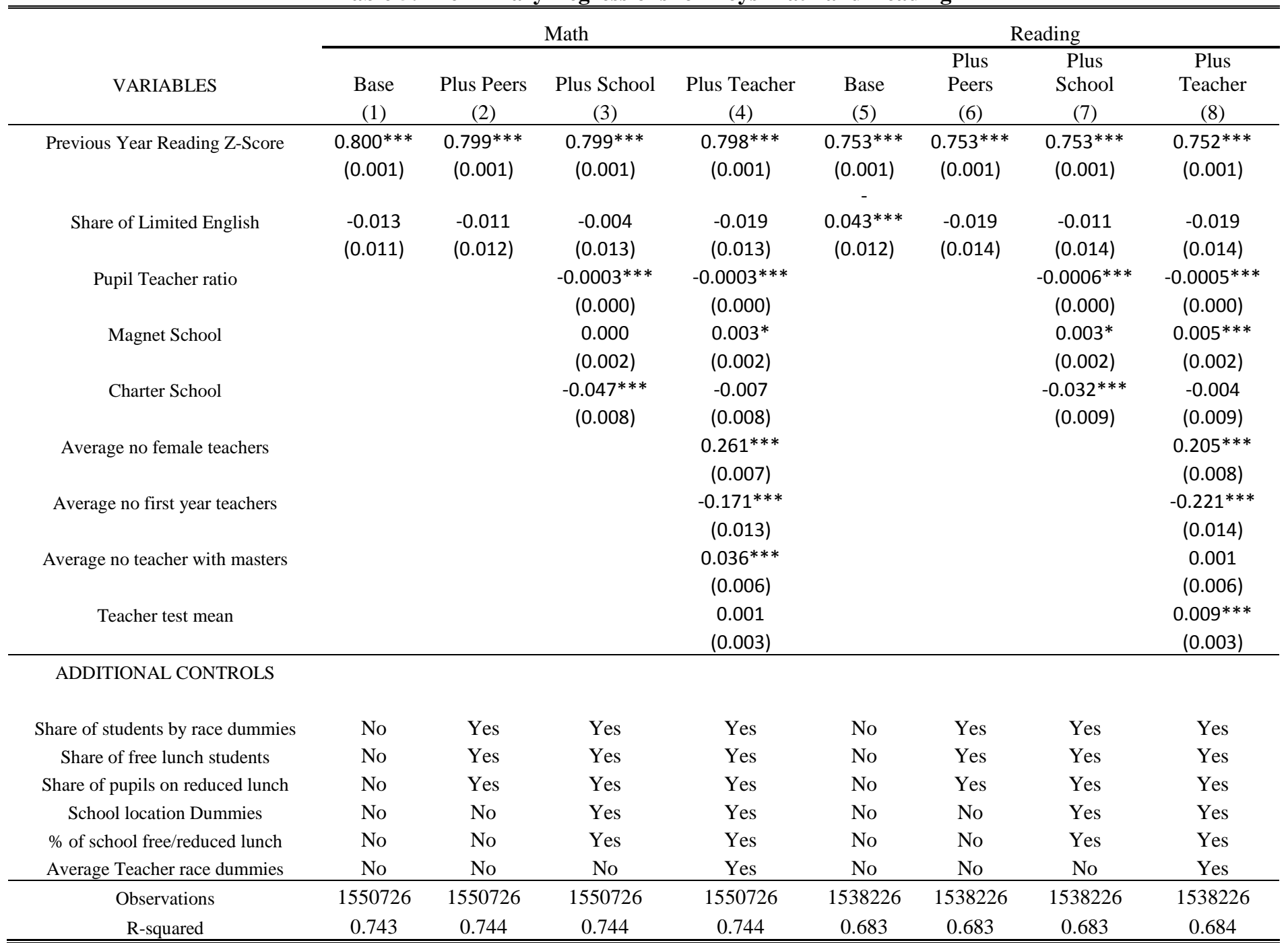

Notes: Robust standard errors in parentheses; ${ }^{* * *} \mathrm{p}<0.01,{ }^{* *} \mathrm{p}<0.05,{ }^{*} \mathrm{p}<0.10$; all specifications include:

grade fixed effects, year fixed effects, race dummies, parent education dummies, and lunch program dummies 
Table 6: Effect of Increases in Immigrant Shares on Achievement by Gender

\begin{tabular}{|c|c|c|c|c|}
\hline & \multicolumn{2}{|c|}{ (Estimates for Math) } & \multicolumn{2}{|c|}{ (Estimates for Reading) } \\
\hline & $\begin{array}{c}\text { School } \\
\text { Fixed Effects } \\
(1) \\
\end{array}$ & $\begin{array}{l}\text { School by Year } \\
\text { Fixed Effects } \\
(2) \\
\end{array}$ & $\begin{array}{c}\text { School } \\
\text { Fixed Effects } \\
(3) \\
\end{array}$ & $\begin{array}{c}\text { School by Year } \\
\text { Fixed Effects } \\
(4)\end{array}$ \\
\hline \multicolumn{5}{|c|}{ Panel A : Female } \\
\hline Share of Limited English & $\begin{array}{c}-0.0289 * * \\
(0.014)\end{array}$ & $\begin{array}{c}-0.0248 \\
(0.033)\end{array}$ & $\begin{array}{c}-0.0488^{* * *} \\
(0.015)\end{array}$ & $\begin{array}{l}-0.0412 \\
(0.036)\end{array}$ \\
\hline Observations & $1,543,554$ & $1,543,554$ & $1,539,292$ & $1,539,292$ \\
\hline R-squared & 0.747 & 0.755 & 0.686 & 0.691 \\
\hline \multicolumn{5}{|c|}{ Panel B: Male } \\
\hline Share of Limited English & $\begin{array}{l}-0.0199 \\
(0.014)\end{array}$ & $\begin{array}{c}-0.0742 * * \\
(0.034)\end{array}$ & $\begin{array}{l}-0.0233 \\
(0.016)\end{array}$ & $\begin{array}{c}-0.0719 * \\
(0.038)\end{array}$ \\
\hline Observations & $1,550,726$ & $1,550,726$ & $1,538,226$ & $1,538,226$ \\
\hline R-squared & 0.748 & 0.756 & 0.686 & 0.691 \\
\hline
\end{tabular}


Table 7: Effect of Increases in LES shares on Black achievement

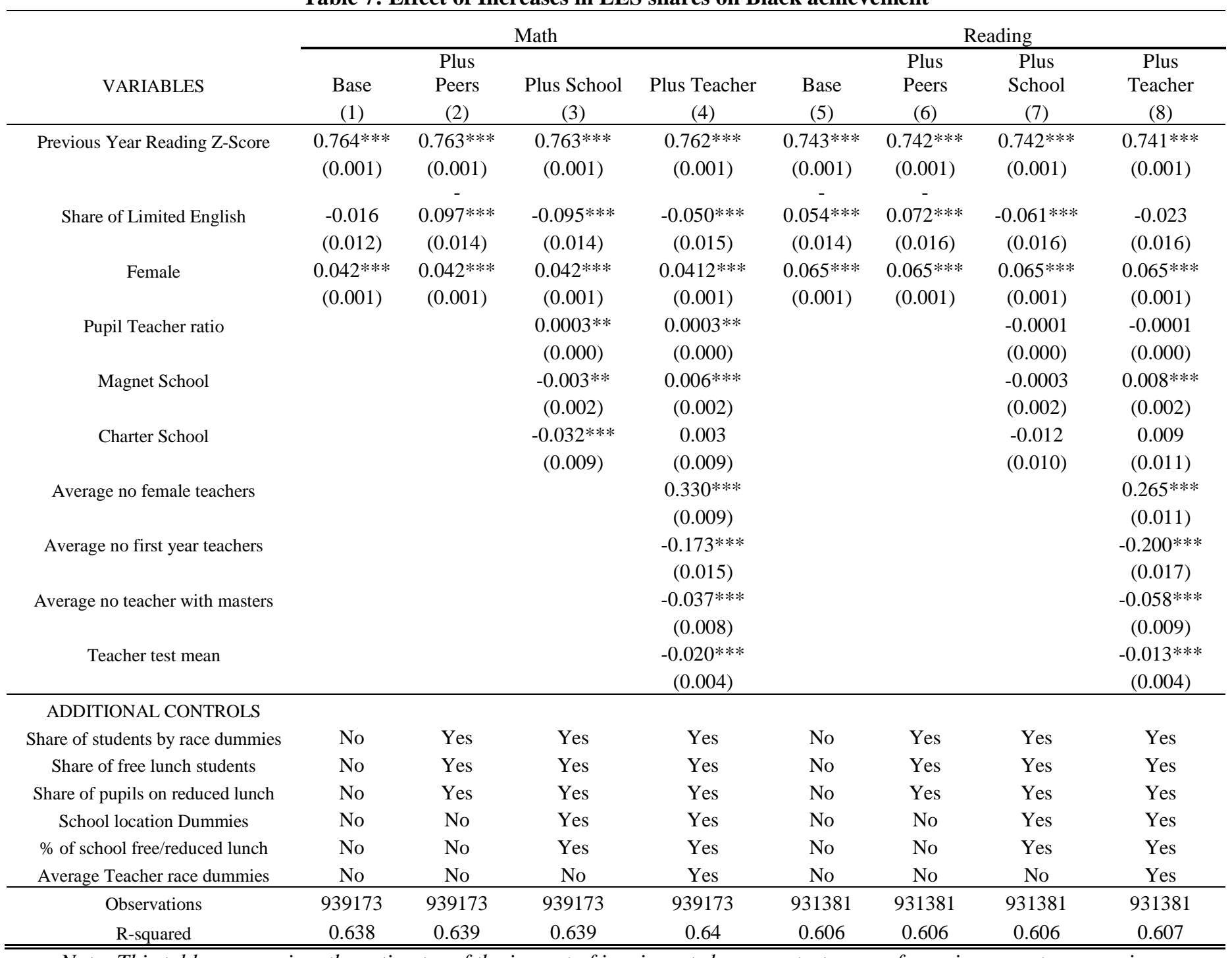

Note: This table summarizes the estimates of the impact of immigrant shares on test scores from six separate regressions.

The controls highlighted in Table 4 are also included in each regression. 
Table 8: Effect of Increases in LES Shares on Achievement by White Students

\begin{tabular}{|c|c|c|c|c|c|c|c|c|}
\hline \multirow[b]{2}{*}{ VARIABLES } & \multicolumn{4}{|c|}{ Math } & \multicolumn{4}{|c|}{ Reading } \\
\hline & $\begin{array}{c}\text { Base } \\
(1) \\
\end{array}$ & $\begin{array}{c}\text { Plus Peers } \\
(2) \\
\end{array}$ & $\begin{array}{c}\text { Plus School } \\
(3) \\
\end{array}$ & $\begin{array}{c}\text { Plus Teacher } \\
(4) \\
\end{array}$ & $\begin{array}{c}\text { Base } \\
(5) \\
\end{array}$ & $\begin{array}{c}\text { Plus Peers } \\
(6) \\
\end{array}$ & $\begin{array}{c}\text { Plus School } \\
(7) \\
\end{array}$ & $\begin{array}{c}\text { Plus Teacher } \\
(8) \\
\end{array}$ \\
\hline Previous Year Reading Z-Score & $\begin{array}{c}0.815 * * * \\
(0.000)\end{array}$ & $\begin{array}{c}0.814 * * * \\
(0.000)\end{array}$ & $\begin{array}{c}0.814^{* * *} \\
(0.000)\end{array}$ & $\begin{array}{c}0.813^{* * *} \\
(0.000)\end{array}$ & $\begin{array}{c}0.757^{* * * *} \\
(0.001)\end{array}$ & $\begin{array}{c}0.757^{* * *} \\
(0.001)\end{array}$ & $\begin{array}{c}0.756^{* * *} \\
(0.001)\end{array}$ & $\begin{array}{c}0.756^{* * *} \\
(0.001)\end{array}$ \\
\hline Share of Limited English & $\begin{array}{c}-0.041 * * * \\
(0.010)\end{array}$ & $\begin{array}{l}-0.005 \\
(0.012)\end{array}$ & $\begin{array}{l}-0.0008 \\
(0.012)\end{array}$ & $\begin{array}{l}-0.016 \\
(0.012)\end{array}$ & $\begin{array}{c}-0.048 * * * \\
(0.011)\end{array}$ & $\begin{array}{c}-0.035^{* * *} \\
(0.013)\end{array}$ & $\begin{array}{c}-0.032 * * \\
(0.013)\end{array}$ & $\begin{array}{c}-0.038^{* * *} \\
(0.013)\end{array}$ \\
\hline Female & $\begin{array}{c}0.012^{* * *} \\
(0.001)\end{array}$ & $\begin{array}{c}0.012^{* * *} \\
(0.001)\end{array}$ & $\begin{array}{c}0.012^{* * *} \\
(0.001)\end{array}$ & $\begin{array}{c}0.012^{* * *} \\
(0.001)\end{array}$ & $\begin{array}{c}0.041^{* * *} \\
(0.001)\end{array}$ & $\begin{array}{c}0.041^{* * *} \\
(0.001)\end{array}$ & $\begin{array}{c}0.041^{* * *} \\
(0.001)\end{array}$ & $\begin{array}{c}0.041^{* * *} \\
(0.001)\end{array}$ \\
\hline Pupil Teacher ratio & & & $\begin{array}{c}-0.0005^{* * *} \\
(0.000)\end{array}$ & $\begin{array}{c}-0.0003^{* * *} \\
(0.000)\end{array}$ & & & $\begin{array}{c}-0.0008 * * * \\
(0.000)\end{array}$ & $\begin{array}{c}-0.0006^{* * *} \\
(0.000)\end{array}$ \\
\hline Magnet School & & & $\begin{array}{l}0.0005 \\
(0.002)\end{array}$ & $\begin{array}{l}0.0003 \\
(0.002)\end{array}$ & & & $\begin{array}{c}0.010 * * * \\
(0.002)\end{array}$ & $\begin{array}{c}0.008^{* * *} \\
(0.002)\end{array}$ \\
\hline Charter School & & & $\begin{array}{c}-0.087^{* * *} \\
(0.007)\end{array}$ & $\begin{array}{c}-0.051 * * * \\
(0.007)\end{array}$ & & & $\begin{array}{c}-0.052^{* * *} \\
(0.008)\end{array}$ & $\begin{array}{c}-0.025^{* * *} \\
(0.008)\end{array}$ \\
\hline Average no female teachers & & & & $\begin{array}{c}0.204^{* * *} \\
(0.006)\end{array}$ & & & & $\begin{array}{c}0.127^{* * *} \\
(0.006)\end{array}$ \\
\hline Average no first year teachers & & & & $\begin{array}{c}-0.151 * * * \\
(0.011)\end{array}$ & & & & $\begin{array}{c}-0.191^{* * *} \\
(0.012)\end{array}$ \\
\hline Average no teacher with masters & & & & $\begin{array}{c}0.059 * * * \\
(0.005)\end{array}$ & & & & $\begin{array}{c}0.041^{* * *} \\
(0.005)\end{array}$ \\
\hline Teacher test mean & & & & $\begin{array}{c}0.007 * * * \\
(0.002)\end{array}$ & & & & $\begin{array}{c}0.021^{* * *} \\
(0.003)\end{array}$ \\
\hline $\begin{array}{l}\text { ADDITIONAL CONTROLS } \\
\text { Share of students by race dummies }\end{array}$ & No & Yes & Yes & Yes & No & Yes & Yes & Yes \\
\hline Share of free lunch students & No & Yes & Yes & Yes & No & Yes & Yes & Yes \\
\hline Share of pupils on reduced lunch & No & Yes & Yes & Yes & No & Yes & Yes & Yes \\
\hline School location Dummies & No & No & Yes & Yes & No & No & Yes & Yes \\
\hline$\%$ of school free/reduced lunch & No & No & Yes & Yes & No & No & Yes & Yes \\
\hline Average Teacher race dummies & No & No & No & Yes & No & No & No & Yes \\
\hline Observations & $1,983,408$ & $1,983,408$ & $1,983,408$ & $1,983,408$ & $1,975,386$ & $1,975,386$ & $1,975,386$ & $1,975,386$ \\
\hline R-squared & 0.724 & 0.724 & 0.724 & 0.725 & 0.657 & 0.657 & 0.657 & 0.657 \\
\hline
\end{tabular}


Table 9: Effect of Increases in LES Shares on Achievement by race (Fixed Effects)

\begin{tabular}{ccccc}
\hline \hline & \multicolumn{2}{c}{ (Math) } & \multicolumn{2}{c}{ (Reading) } \\
\hline & School & School by Year & School & School by Year \\
& Fixed Effects & Fixed Effects & Fixed Effects & Fixed Effects \\
& & & & \\
& $(1)$ & $(2)$ & $(3)$ & $(4)$ \\
\hline Share of Limited English & $-0.0442^{* *}$ & $-0.0844^{* *}$ & $-0.0525^{* * *}$ & $-0.104^{* *}$ \\
& $(0.017)$ & $(0.040)$ & $(0.020)$ & $(0.046)$ \\
Observations & 939,173 & 939,173 & 931,381 & 931,381 \\
R-squared & 0.647 & 0.66 & 0.611 & 0.62 \\
\hline \multirow{5}{*}{ Share of Limited English } & $-0.0385^{* * *}$ & -0.0346 & $-0.0571^{* * *}$ & -0.0393 \\
& $(0.014)$ & $(0.031)$ & $(0.015)$ & $(0.034)$ \\
Observations & $1,983,408$ & $1,983,408$ & $1,975,386$ & $1,975,386$ \\
R-squared & 0.73 & 0.737 & 0.659 & 0.664 \\
\hline \hline
\end{tabular}


Table 10: Effect of Increases in LES Shares on test scores by race and gender

\begin{tabular}{|c|c|c|c|c|}
\hline & \multicolumn{2}{|c|}{ (Math) } & \multicolumn{2}{|c|}{ (Reading) } \\
\hline & $\begin{array}{c}\text { School } \\
\text { Fixed Effects } \\
(1)\end{array}$ & $\begin{array}{c}\text { School by Year } \\
\text { Fixed Effects } \\
(2)\end{array}$ & $\begin{array}{c}\text { School } \\
\text { Fixed Effects } \\
(3) \\
\end{array}$ & $\begin{array}{c}\text { School by Year } \\
\text { Fixed Effects } \\
(4)\end{array}$ \\
\hline \multicolumn{5}{|c|}{ Panel A: Female Black } \\
\hline Share of Limited English & $-0.0564 * *$ & -0.0627 & $-0.0630^{* *}$ & -0.0687 \\
\hline & $(0.024)$ & $(0.056)$ & $(0.026)$ & $(0.062)$ \\
\hline Observations & 478,613 & 478,613 & 476,620 & 476,620 \\
\hline R-squared & 0.656 & 0.672 & 0.615 & 0.627 \\
\hline \multicolumn{5}{|c|}{ Panel B: Female White } \\
\hline Share of Limited English & $-0.0343^{*}$ & 0.0337 & $-0.0715^{* * *}$ & -0.0153 \\
\hline & $(0.019)$ & $(0.043)$ & $(0.021)$ & $(0.047)$ \\
\hline Observations & 978,221 & 978,221 & 976,173 & 976,173 \\
\hline R-squared & 0.731 & 0.74 & 0.656 & 0.663 \\
\hline \multicolumn{5}{|c|}{ Panel C: Male Black } \\
\hline Share of Limited English & -0.0344 & -0.0969 & -0.0433 & $-0.127^{*}$ \\
\hline & $(0.025)$ & $(0.060)$ & $(0.029)$ & $(0.069)$ \\
\hline Observations & 460,560 & 460,560 & 454,761 & 454,761 \\
\hline R-squared & 0.637 & 0.654 & 0.597 & 0.61 \\
\hline \multicolumn{5}{|c|}{ Panel D: Male White } \\
\hline Share of Limited English & $-0.0435^{* *}$ & $-0.0933 * *$ & $-0.0467 * *$ & -0.0535 \\
\hline & $(0.020)$ & $(0.045)$ & $(0.022)$ & $(0.049)$ \\
\hline Observations & $1,005,187$ & $1,005,187$ & 999,213 & 999,213 \\
\hline R-squared & 0.729 & 0.737 & 0.659 & 0.665 \\
\hline
\end{tabular}

Note: This table summarizes the estimates of the impact of immigrant shares on test scores from sixteen separate regressions. The controls highlighted in Table 3 are also included in each regression. 
Table 11: Effect of Increases in LES Shares on Test Scores for Black Students by Gender and Achievement

\begin{tabular}{|c|c|c|c|c|c|c|}
\hline & \multicolumn{3}{|c|}{ (Math) } & \multicolumn{3}{|c|}{ (Reading) } \\
\hline & Top 33.3\% & $\begin{array}{l}\text { Middle } \\
33.33 \%\end{array}$ & $\begin{array}{l}\text { Bottom } \\
33.33 \%\end{array}$ & $\begin{array}{c}\text { Top } \\
\text { 33.33\% }\end{array}$ & $\begin{array}{l}\text { Middle } \\
33.33 \%\end{array}$ & $\begin{array}{l}\text { Bottom } \\
33.33 \%\end{array}$ \\
\hline & (1) & (2) & (3) & (4) & (5) & (6) \\
\hline \multicolumn{7}{|c|}{ Panel A: Black Female Students } \\
\hline Share of Limited & & & & & & \\
\hline \multirow[t]{2}{*}{ English } & -0.0711 & $-0.068 *$ & -0.034 & -0.104 & $-0.134 * * *$ & -0.095 \\
\hline & $(0.107)$ & $(0.045)$ & $(0.062)$ & (0.096) & (0.043) & (0.079) \\
\hline Observations & 75,622 & 147,808 & 255,183 & 92,513 & 171,549 & 212,558 \\
\hline R-squared & 0.432 & 0.229 & 0.345 & 0.298 & 0.199 & 0.332 \\
\hline \multicolumn{7}{|c|}{ Panel B: Black Male Students } \\
\hline Share of Limited & & & & & & \\
\hline English & -0.085 & 0.0321 & -0.063 & $-0.257 * *$ & $-0.151 * * *$ & -0.083 \\
\hline & $(0.120)$ & $(0.049)$ & $(0.064)$ & $(0.110)$ & (0.049) & $(0.081)$ \\
\hline Observations & 63,721 & 127,496 & 269,343 & 66,202 & 141,732 & 246,827 \\
\hline R-squared & 0.433 & 0.218 & 0.346 & 0.308 & 0.193 & 0.345 \\
\hline
\end{tabular}

Note: This table summarizes the estimates of the impact of LES shares on test scores from twelve separate regressions. The controls highlighted in Table 3 are also included in each regression.

Table 12: Effect of Increases in LES Shares on Test Scores for Whites by Gender and Achievement

\begin{tabular}{|c|c|c|c|c|c|c|}
\hline & \multicolumn{3}{|c|}{ (Math) } & \multicolumn{3}{|c|}{ (Reading) } \\
\hline & Top 33.3\% & $\begin{array}{l}\text { Middle } \\
33.33 \%\end{array}$ & $\begin{array}{l}\text { Bottom } \\
33.33 \%\end{array}$ & $\begin{array}{c}\text { Top } \\
33.33 \%\end{array}$ & $\begin{array}{l}\text { Middle } \\
33.33 \%\end{array}$ & $\begin{array}{l}\text { Bottom } \\
33.33 \%\end{array}$ \\
\hline & (1) & (2) & (3) & (4) & (5) & (6) \\
\hline \multicolumn{7}{|c|}{ Panel A: White Female Students } \\
\hline Share of Limited & & & & & & \\
\hline \multirow[t]{2}{*}{ English } & -0.067 & -0.0191 & 0.0204 & -0.0713 & 0.00775 & -0.0521 \\
\hline & $(0.054)$ & $(0.034)$ & $(0.069)$ & $(0.050)$ & $(0.035)$ & $(0.096)$ \\
\hline Observations & 452,291 & 307,184 & 218,746 & 501,521 & 307,917 & 166,735 \\
\hline R-squared & 0.484 & 0.206 & 0.334 & 0.328 & 0.185 & 0.329 \\
\hline \multicolumn{7}{|c|}{ Panel B: White Male Students } \\
\hline Share of Limited & & & & & & \\
\hline English & $-0.134 * *$ & -0.0205 & 0.0453 & $-0.0861 *$ & $-0.118 * * *$ & -0.000964 \\
\hline & $(0.055)$ & $(0.035)$ & $(0.070)$ & $(0.052)$ & $(0.035)$ & $(0.093)$ \\
\hline Observations & 472,896 & 294,107 & 238,184 & 463,145 & 315,856 & 220,212 \\
\hline R-squared & 0.48 & 0.187 & 0.329 & 0.301 & 0.17 & 0.339 \\
\hline
\end{tabular}

Note: This table summarizes the estimates of the impact of LES shares on test scores from twelve separate regressions. The controls highlighted in Table 3 are also included in each regression. 